\section{VOLUME 77 ISSUE 1 - JAN/FEB 2011}

Correcting of references:

Primary mucosal melanoma of the sinonasal tract: Report of 18 patients and analysis of 1077 patients in the literature

Bijan Khademi $\bullet$ Hajar Babranifard $\bullet$ Hamid Nasrollahi $\bullet$ Mohammad Mohammadianpanah

11. Khademi B, Moradi A, Hoseini S, Mohammadianpanah M. Malignant neoplasms of the sinonasal tract: report of 71 patients and literature review and analysis. Oral Maxillofac Surg.2009;13:191-9

12. Cantu G, Bimbi G, Fabiani F, et al. [Lymph node metastases in paranasal sinus carcinoma: prognostic value and treatment]. Acta Otorhinolaryngol Ital.2002;22:273-9.

13. Harbo G, Grau C, Bundgaard T, Overgaard M, Elbrond O, Sogaard $\mathrm{H}$, Overgaard J. Cancer of the nasal cavity and paranasal sinuses. A clinico-pathological study of 277 patients. Acta Oncol.1997;36:45-50.

14. Huang SF, Liao CT, Kan CR, Chen IH. Primary mucosal melanoma of the nasal cavity and paranasal sinuses: 12 years of experience. $\mathrm{J}$ Otolaryngol.2007;36:124-9.

15. Wagner M, Morris CG, Werning JW, Mendenhall WM. Mucosal melanoma of the head and neck. Am J Clin Oncol.2008;31:43-8.

16. Dauer EH, Lewis JE, Rohlinger AL, Weaver AL, Olsen KD. Sinonasal melanoma: a clinicopathologic review of 61 cases. Otolaryngol Head Neck Surg.2008;138:347-52.

17. Pomar Blanco P, San Roman Carbajo J, Bouso Montero M, Martin Villares C, Fernandez Pello M, Tapia Risueno M. [Sinonasal mucosal melanoma]. An Otorrinolaringol Ibero Am.2007;34:349-58.

18. Peng RQ, Wu GH, Chen WK, et al. [Clinical characteristics and prognosis of primary nasal mucosal melanoma--a report of 44 cases]. Ai Zheng.2006;25:1284-6.

19. Martin JM, Porceddu S, Weih L, Corry J, Peters LJ. Outcomes in sinonasal mucosal melanoma. ANZ J Surg.2004;74:838-42.

20. Prasad ML, Busam KJ, Patel SG, Hoshaw-Woodard S, Shah JP, Huvos AG. Clinicopathologic differences in malignant melanoma arising in oral squamous and sinonasal respiratory mucosa of the upper aerodigestive tract. Arch Pathol Lab Med.2003;127:997-1002.

21. Temam S, Mamelle G, Marandas P, et al. Postoperative radiotherapy for primary mucosal melanoma of the head and neck. Cancer.2005; 103:313-9.

22. Thompson LD, Wieneke JA, Miettinen M. Sinonasal tract and nasopharyngeal melanomas: a clinicopathologic study of 115 cases with a proposed staging system. Am J Surg Pathol.2003;27:594-611.

23. Oueslati Z, Touati S, Gritli S, et al. [Mucous malignant melanoma of the neck and face. Experience at the Salah Azaiz Institute (Tunis)]. Rev Laryngol Otol Rhinol (Bord).2001;122:237-40.

24. Slavícek A, Astl J, Válková D, Betka J, Petruzelka L. [Malignant mucosal melanoma of the head and neck]. Sb Lek.2000;101:315-23.

25. Ryuto M, Higaki Y, Tomita K. [Clinical analysis of 16 cases of malignant head and neck melanoma]. Nippon Jibiinkoka Gakkai Kaiho.2001;104:859-65.

26. Díaz Molina JP, Rodrigo Tapia JP, Llorente Pendas JL, Suárez Nieto C. [Sinonasal mucosal melanomas. Review of 17 case.]. Acta Otorrinolaringol Esp.2008;59:489-93.

27. Cheng YF, Lai CC, Ho CY, Shu CH, Lin CZ. Toward a better understanding of sinonasal mucosal melanoma: clinical review of 23 cases. J Chin Med Assoc.2007;70:24-9.

28. Regauer S, Anderhuber W, Richtig E, Schachenreiter J, Ott A, Beham A. Primary mucosal melanomas of the nasal cavity and paranasal sinuses. A clinicopathological analysis of 14 cases. Apmis.1998;106:403-10.

29. Folz BJ, Niemann AM, Lippert BM, Hauschild A, Werner JA. [Mucous membrane melanomas of the upper aerodigestive tract. An analysis of 34 cases]. Laryngorhinootologie.1997;76:289-94.

30. Brandwein MS, Rothstein A, Lawson W, Bodian C, Urken ML. Sinonasal melanoma. A clinicopathologic study of 25 cases and literature meta-analysis. Arch Otolaryngol Head Neck Surg.1997;123:290-6.

31. Bridger AG, Smee D, Baldwin MA, Kwok B, Bridger GP. Experience with mucosal melanoma of the nose and paranasal sinuses. ANZ J Surg.2005;75:192-7.
32. Patel SG, Prasad ML, Escrig M, et al. Primary mucosal malignant melanoma of the head and neck. Head Neck.2002;24:247-57.

33. Faye-Lund H, Larsen TE. [Mucosal malignant melanomas of the head and neck]. Tidsskr Nor Laegeforen.1999;119:789-91.

34. Nandapalan V, Roland NJ, Helliwell TR, Williams EM, Hamilton JW, Jones AS. Mucosal melanoma of the head and neck. Clin Otolaryngol Allied Sci.1998;23:107-16.

35. Kingdom TT, Kaplan MJ. Mucosal melanoma of the nasal cavity and paranasal sinuses. Head Neck.1995;17:184-9.

36. Lund VJ, Howard DJ, Harding L, Wei WI. Management options and survival in malignant melanoma of the sinonasal mucosa. Laryngoscope.1999;109:208-11.

37. Bachar G, Loh KS, O'Sullivan B, Goldstein D, Wood S, Brown D, Irish J. Mucosal melanomas of the head and neck: experience of the Princess Margaret Hospital. Head Neck.2008;30:1325-31.

38. Gaze MN, Kerr GR, Smyth JF. Mucosal melanomas of the head and neck: The Scottish experience. The Scottish Melanoma Group. Clin Oncol (R Coll Radiol).1990;2:277-83.

39. Guzzo M, Grandi C, Licitra L, Podrecca S, Cascinelli N, Molinari R. Mucosal malignant melanoma of head and neck: forty-eight cases treated at Istituto Nazionale Tumori of Milan. Eur J Surg Oncol.1993;19:316-9.

40. Owens JM, Roberts DB, Myers JN. The role of postoperative adjuvant radiation therapy in the treatment of mucosal melanomas of the head and neck region. Arch Otolaryngol Head Neck Surg.2003;129:864-8.

41. Hyodo M, Sato H, Yamagata T, Hato N, Aritomo H. Sinonasal malignant melanoma; clinical analysis of 14 cases. Practica Oto-RhinoLaryngologica.1996;2:121-6

42. Meleti M, Leemans CR, de Bree R, Vescovi P, Sesenna E, van der Waal I. Head and neck mucosal melanoma: experience with 42 patients, with emphasis on the role of postoperative radiotherapy. Head Neck.2008;30:1543-51

43. Kumar S, Gupta AK, Yadav BS, Ghoshal S. Primary sinonasal malignant melanoma: a clinicopathologic and prognostic study. Ear Nose Throat J.2009;88:1269-72.

44. Nakaya M, Mochiki M, Takeuchi S, Yuge T, Nakao K, Nakamura N. Malignant melanoma of nasal cavity: report of 16 Japanese patients. Auris Nasus Larynx.2004;31:233-7

45. Shah JP, Huvos AG, Strong EW. Mucosal melanomas of the head and neck. Am J Surg.1977;134:531-5.

46. Krengli M, Jereczek-Fossa BA, Kaanders JH, Masini L, Beldi D, Orecchia R. What is the role of radiotherapy in the treatment of mucosal melanoma of the head and neck? Crit Rev Oncol Hematol.2008;65:121-8.

47. Wada H, Nemoto K, Ogawa Y, et al. A multi-institutional retrospective analysis of external radiotherapy for mucosal melanoma of the head and neck in Northern Japan. Int J Radiat Oncol Biol Phys.2004;59:495500.

48. Lee SP, Shimizu KT, Tran LM, Juillard G, Calcaterra TC. Mucosal melanoma of the head and neck: the impact of local control on survival. Laryngoscope.1994;104:121-6.

49. Trotti A, Peters LJ. Role of radiotherapy in the primary management of mucosal melanoma of the head and neck. Semin Surg Oncol.1993;9:246-50

50. Markovic SN, Erickson LA, Rao RD, et al. Malignant melanoma in the 21st century, part 1: epidemiology, risk factors, screening, prevention, and diagnosis. Mayo Clin Proc.2007;82:364-80.

51. Eggermont AMM, Kirkwood JM: Re-evaluating the role of dacarbazine in metastatic melanoma: What have we learned in 30 years? Eur J Cancer.2004;40:1825-36

52. Nashan D, Muller ML, Grabbe S, Wustlich S, Enk A. Systemic therapy of disseminated malignant melanoma: an evidence-based overview of the state-of-the-art in daily routine. J Eur Acad Dermatol Venereol.2007;21:1305-18.

53. Sasse AD, Sasse EC, Clark LG, Ulloa L, Clark OA. Chemoimmunotherapy versus chemotherapy for metastatic malignant melanoma. Cochrane Database Syst Rev.2007:CD005413.

54. Kasper B, D'Hondt V, Vereecken P, Awada A. Novel treatment strategies for malignant melanoma: a new beginning? Crit Rev Oncol Hematol.2007;62:16-22. 